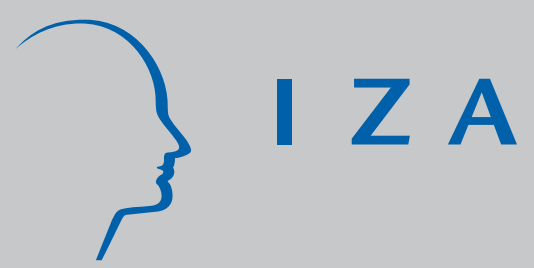

IZA DP No. 363

Immigration Policy and the Skills of Immigrants to Australia, Canada, and the United States

Heather Antecol

Deborah A. Cobb-Clark

Stephen J. Trejo

September 2001 


\title{
Immigration Policy and the Skills of Immigrants to Australia, Canada, and the United States
}

\author{
Heather Antecol \\ Department of Economics, Claremont McKenna College \\ Deborah A. Cobb-Clark \\ SPEAR Centre, RSSS, Australian National University, Canberra and IZA, Bonn \\ Stephen J. Trejo \\ Department of Economics, University of Texas and IZA, Bonn
}

\author{
Discussion Paper No. 363 \\ September 2001
}

\author{
IZA \\ P.O. Box 7240 \\ D-53072 Bonn \\ Germany \\ Tel.: +49-228-3894-0 \\ Fax: +49-228-3894-210 \\ Email: iza@iza.org
}

This Discussion Paper is issued within the framework of IZA's research area Internationalization of Labor Markets and European Integration. Any opinions expressed here are those of the author(s) and not those of the institute. Research disseminated by IZA may include views on policy, but the institute itself takes no institutional policy positions.

The Institute for the Study of Labor (IZA) in Bonn is a local and virtual international research center and a place of communication between science, politics and business. IZA is an independent, nonprofit limited liability company (Gesellschaft mit beschränkter Haftung) supported by the Deutsche Post AG. The center is associated with the University of Bonn and offers a stimulating research environment through its research networks, research support, and visitors and doctoral programs. IZA engages in (i) original and internationally competitive research in all fields of labor economics, (ii) development of policy concepts, and (iii) dissemination of research results and concepts to the interested public. The current research program deals with (1) mobility and flexibility of labor markets, (2) internationalization of labor markets and European integration, (3) the welfare state and labor markets, (4) labor markets in transition, (5) the future of work, (6) project evaluation and (7) general labor economics.

IZA Discussion Papers often represent preliminary work and are circulated to encourage discussion. Citation of such a paper should account for its provisional character. 
IZA Discussion Paper No. 363

September 2001

\section{ABSTRACT \\ Immigration Policy and the Skills of Immigrants to Australia, Canada, and the United States}

Census data for 1990/91 indicate that Australian and Canadian immigrants have higher levels of English fluency, education, and income (relative to natives) than do U.S. immigrants. This skill deficit for U.S. immigrants arises primarily because the United States receives a much larger share of immigrants from Latin America than do the other two countries. After excluding Latin American immigrants, the observable skills of immigrants are similar in the three countries. These patterns suggest that the comparatively low overall skill level of U.S. immigrants may have more to do with geographic and historical ties to Mexico than with the fact that skill-based admissions are less important in the United States than in Australia and Canada.

JEL Classification: J61, J68, J31

Keywords: Immigration, immigrant skills, immigration policy

Steve Trejo

Department of Economics

University of Texas

Austin, TX 78712-1173

USA

Tel.: +1 (512) 475-8512

Fax: +1 (512) 471-3510

Email: trejo@eco.utexas.edu 


\section{Introduction}

Australia, Canada, and the United States share a common history as major immigrant-receiving countries. ${ }^{1}$ In this paper, we compare the observable skills-language fluency, education, and income-of immigrants to these three countries. These countries provide fertile ground for comparative analysis because although their economies are similar in many fundamental respects, labor market policies and institutions differ markedly, and this institutional variation provides a promising avenue for identifying the labor market effects of government policy. In addition, high-quality census microdata are available for each of these countries that make it possible to conduct detailed and comparable analyses of labor market outcomes.

The topic of immigration is especially ripe for such a comparative analysis, because this is an area where researchers and policymakers in the United States could learn a great deal from the experiences of Australia and Canada. Of particular interest are the attempts Australia and Canada have made to screen for workers with special skills or high levels of education (Boyd 1976; Price 1979; Green and Green 1995). These attempts run counter to the family reunification emphasis of U.S. immigration policy. In the United States, concerns have arisen over the declining education and skill levels of successive immigrant waves (Borjas 1995). Such concerns are reflected in provisions of the Immigration Act of 1990 that seek to increase the share of immigrants admitted on the basis of their work skills, and these concerns have also prompted proposals to introduce more explicitly skill-based admissions criteria like those used in Australia and Canada. Before pushing ahead with this kind of immigration reform, however, it would be prudent to consider the consequences of such policies in Australia and Canada.

Furthermore, even if we put aside differences in immigration policy, structural and institutional differences in the labor markets of the three countries are likely to influence the type of immigrants who are attracted to each destination. For a number of reasons (stronger labor unions, higher minimum wages, national health insurance, more generous unemployment insurance and welfare systems), workers in the lower end of the income

\footnotetext{
${ }^{1}$ During the period 1975-80, for example, nearly two-thirds of all immigrants chose one of these three countries as their destination (Borjas 1991). More recently, other countries have emerged as important immigrant destinations, but Australia, Canada, and the United States remain dominant receiving countries.
} 
distribution are generally better off in Australia and Canada than in the United States, especially relative to the average worker in each country (Card and Freeman 1993; Gregory and Daly 1994). Furthermore, although all three countries have experienced widening income inequality over the past two decades, in the United States real incomes have fallen sharply for low-skill workers, whereas in Australia and Canada the corresponding decline in the bottom half of the income distribution has been much more modest (Freeman and Katz 1994). A comparative analysis may therefore shed light on how ongoing changes in the U.S. wage structure will affect the skill composition of the immigrant flows that the United States attracts and how these immigrants are likely to fare in the U.S. labor market.

To illustrate our strategy, consider the question of which country should attract the most skilled immigrant flow. On the one hand, the Australian and Canadian practice of admitting a large fraction of immigrants through a "point system" that screens for labor market skills suggests that these countries should receive a more skilled immigrant flow than the United States. On the other hand, the theory of selective migration (Borjas 1991) predicts that the generous redistribution systems and relatively egalitarian wage structures in Australia and Canada work in the opposite direction by attracting less skilled immigrants who will reside in the bottom half of the income distribution. On the surface, then, it is difficult to determine how differences in immigration policies and government institutions across countries should affect the selectivity of immigration flows to the three destination countries.

To a large extent, however, the immigration point systems employed in Australia and Canada select immigrants based on easily observed characteristics such as age, education, language, and occupation. In terms of these characteristics, immigrants to Australia and Canada should be more productive than those migrating to the United States. Our tests of this hypothesis will reveal how successful immigration point systems are, in practice, at selecting immigrants with favorable skill measures, and how much this screening process raises the labor market productivity of immigrant workers. ${ }^{2}$

\footnotetext{
${ }^{2}$ For several reasons, it is not a foregone conclusion that the Australian and Canadian systems lead to an immigrant flow that is highly selective in terms of characteristics associated with labor market success. First, both systems admit many immigrants who are not screened by a points test, including applicants with immediate family who are citizens of the destination country, refugees, and the family members who accompany those admitted by a points test. Second, both systems award a significant number of points based on a "personal assessment" of the applicant by the immigration official conducting the face-to-face interview. Finally, Reitz (1998) argues that the Australian and Canadian point systems can be
} 
Interestingly, the opposite pattern should emerge if we first control for the characteristics that immigrant point systems screen on. In particular, among immigrants with similar observable skill measures, the most productive should locate in the United States where there is less social insurance against poor labor market outcomes but a greater individual return to favorable outcomes. Our tests of this hypothesis will indicate to what extent immigrant locational choices based on difficult-to-observe attributes, such as ability and ambition, are able to undo the selectivity intended by point systems. Alternatively, a finding that Australian and Canadian immigrants are superior to U.S. immigrants in terms of unobservable as well as observable determinants of earnings would suggest that the "personal assessment" portion of a point system successfully screens for some of the difficult-to-observe attributes related to labor market productivity.

\section{Immigration Policy in Australia, Canada, and the United States}

Tables 1 and 2 present an overview of the immigrant admissions policies of Australia, Canada, and the United States as of around $1990 .{ }^{3}$ Table 1 provides a brief outline of the main components of admissions policies in the three countries, and Table 2 reports the percentages of immigrants who entered under various broad admission categories. Our primary goal is to show that a much larger share of Australian and Canadian immigrants are admitted on the basis of their labor market skills than is the case for U.S. immigrants.

In Australia and Canada, so-called "independent" migrants without relatives in the destination country can gain admission by passing a "points test" that takes into account factors such as the applicant's age, education, language ability, and occupation. Some applicants with relatives in the destination country are also evaluated by a points test, with the number of points required for admission lowered when the family relationship is sufficiently close. ${ }^{4}$ In addition, immigrants can be admitted because they possess special talents or because they meet certain investment requirements and intend to establish a

passed by applicants with quite modest skill levels, and therefore these systems may provide only very weak filters for immigrant labor market skills.

${ }^{3}$ For detailed discussions of immigration policy in these three countries, see Boyd (1976), Briggs (1984), Chiswick (1987), Borjas (1988), Vialet (1989), Cobb-Clark (1990), Reimers and Troper (1992), Green (1995), Green and Green (1995), Lack and Templeton (1995), and Reitz (1998).

${ }^{4}$ Immigrant admissions categories in which entry is determined jointly by a points test and by family relationships include the "concessional" category in Australia and the "assisted relatives" category in Canada. 
business in Australia or Canada. Immigrants entering Australia or Canada through any of the avenues just described are categorized as "skilled" immigrants in Table 2, because the human capital and potential labor market success of these applicants play a key role in their admission. In contrast, "family" immigrants consist of those applicants admitted solely on the basis of having an immediate relative in the destination country, and "refugees" are immigrants fleeing political persecution who are admitted on humanitarian grounds.

U.S. admissions policy distinguishes between two types of family immigrants. "Numerically unlimited" family immigrants are the immediate relatives of U.S. citizens who enter without counting against the overall cap set for annual immigrant admissions. "Numerically limited" family immigrants are the more distant relatives of U.S. citizens and the immediate relatives of U.S. permanent residents who, in 1990, had to enter under one of the relevant preference categories (first, second, fourth, or fifth) that regulate admissions subject to the annual cap. ${ }^{5}$ In Table 2, we label U.S. immigrants entering under the third or sixth preference categories as "skilled" immigrants, because only these immigrants were admitted on the basis of their occupation or labor market skills.

The data assembled in Table 2 show that labor market skills play a much larger role in the immigrant admission policies of Australia and Canada than that of the United States. Around 1990, half of Australian immigrants and almost 40 percent of Canadian immigrants were admitted because of their labor market skills, whereas less than 10 percent of U.S. immigrants gained entry in this way. ${ }^{6}$ Conversely, two-thirds of U.S. immigrants were admitted on the basis of their family relationships, as compared with only a quarter of Australian immigrants and 37 percent of Canadian immigrants. The relative importance of skilled versus family migration varies somewhat across immigrant regions of origin, but for all source regions the share of skilled immigrants is much higher and the share of family

\footnotetext{
${ }^{5}$ The 1990 Immigration Act altered U.S. immigration policy somewhat by introducing a three-track preference system for family-sponsored, employment-based, and diversity immigrants (Vialet and Eig, 1990). Our data pre-date this change in policy, however.

${ }^{6}$ In Table 2, the "skilled" category includes the immediate family members who accompany those admitted on the basis of their labor market skills. Therefore, these figures overstate the number of immigrants granted entry because of their own skills rather than family relationships, but adjusting for this feature of the reported data would not alter the conclusion that the skilled category constitutes a much larger share of immigrant admissions in Australia and Canada than in the United States. In addition, the data in Table 2 pertain only to legal admissions. The sizeable and largely unskilled flow of undocumented immigration to the United States implies that the share of all U.S. immigrants admitted because of their skills is even lower than Table 2 suggests.
} 
immigrants is much lower in Australia and Canada than in the United States.

Table 2 describes immigrant admissions in the three countries as of around 1990, but the same basic pattern existed throughout the 1970s and 1980s, when most of the immigrants we analyze below arrived in their destinations. Since the 1965 Amendments to the Immigration and Nationality Act, the skilled category has made up a very small percentage of the U.S. immigration flow (Reitz 1998). Point systems for screening a substantial portion of immigrant applicants were introduced in Canada in the late 1960s and in Australia in the early 1970s (Green and Green 1995; Reitz 1998). Although the fraction of immigrants admitted under a point system has varied over time, particularly for Canada, throughout this period the percentage of admissions based on labor market criteria has remained much higher in Australia and Canada than in the United States (Wright and Maxim 1993; Reitz 1998).

\section{Data}

We analyze individual-level data from the 1991 Australian and Canadian censuses and the 1990 U.S. census. These censuses provide comparable data on demographic characteristics and labor force behavior, as well as the requisite information on country of birth and year of arrival for immigrants. ${ }^{7}$ The Australian data set constitutes a one- percent sample of the population, the Canadian data set is a three- percent sample, and the U.S. data set is a five- percent sample. ${ }^{8}$ These data sources supply detailed information on many thousands of individuals in each destination country. Such large samples are essential for empirical analyses of immigrants, because immigrants typically constitute a small fraction of the total population, and it is important to disaggregate the immigrant population according to variables such as year of arrival and country of origin.

We restrict our analysis to men between the ages of 25 and 59 who are not

\footnotetext{
${ }^{7}$ In this paper, we use the term "immigrant" as synonymous with foreign-born individuals, in contrast to the official terminology used by the U.S. Immigration and Naturalization Service in which immigrants are legal permanent residents, and other foreigners such as tourists, business travelers, and recent refugee arrivals are "nonimmigrant aliens." The census data analyzed here cannot make such distinctions among foreign-born individuals.

${ }^{8}$ The U.S. sample is much larger than the other two samples. To lighten the computational burden, we employ a .1 percent (or 1 in a 1000) sample of U.S. natives, but we use the full 5 percent sample of U.S. immigrants, and we use the full samples of natives and immigrants available in the Australian and Canadian data. The Australian and Canadian census data are self-weighting, whereas the 1990 U.S. census provides sampling weights that we use in all of the calculations reported in the paper.
} 
institutional residents. We exclude women in order to minimize biases arising from selective labor force participation, and we choose this age range so as to focus on men who have completed their formal schooling and who have a strong attachment to the labor market. Often, we compare outcomes for immigrants with those for natives who reside in the same destination country. In this way, natives can serve as a control for cross-country differences in social or economic conditions or in how the census data were collected. To increase comparability of the native samples and improve their usefulness as a control group, we exclude non-whites from the native (but not the immigrant) samples. ${ }^{9}$ Finally, residents of the Atlantic Provinces and the Territories are excluded from the Canadian samples, because for these individuals the information about country of birth and year of immigration is not reported in sufficient detail.

These restrictions produce final samples of immigrant men totaling approximately 11,500 for Australia, 38,600 for Canada, and 297,000 for the United States. For each destination country, Table 3 displays the region of birth distribution for the immigrants in our samples who arrived within ten years of the census. The most striking difference in the national origin composition of recent immigrants to the three countries involves Latin America. Almost half of post-1980 immigrants to the United States hail from Central or South America (including Mexico and the Caribbean), whereas only 14 percent of Canadian immigrants and 2 percent of Australian immigrants come from this region. In addition, the United States receives relatively fewer immigrants from the United Kingdom and Europe than do the other countries: immigrants from these regions comprise 11 percent of the U.S. immigration flow as compared to 26 percent of the Canadian flow and 33 percent of the Australian flow. ${ }^{10}$ Another difference is that Asians make up a somewhat larger share of the immigrant flow to Australia (36 percent) and Canada (40 percent) than to the United States (28 percent). Lastly, note that Australia receives a sizeable number of immigrants from New Zealand.

In the sections that follow, we examine in turn three different measures of immigrant labor market skills: fluency in the language of the destination country, years of schooling,

\footnotetext{
${ }^{9}$ In particular, we exclude blacks, Asians, Hispanics, and aboriginals from the native sample for each destination country.

${ }^{10}$ In Table 3, Europe is defined to include the former USSR.
} 
and income. Our analysis will show that the national origin differences documented in Table 3 - particularly the large share of U.S. immigrants from Latin America-explain most of the observed skill differences between immigrants to the three destination countries.

\section{Fluency in the Destination Country Language}

The Australian and U.S. censuses provide very similar measures of English language proficiency. Respondents were first asked whether they speak a language other than English at home, and then only those who answered affirmatively were asked how well they speak English, with possible responses of "very well," well," "not well," or "not at all." For the Australian and U.S. data, we define individuals as "fluent in the destination country language" if they speak only English or else report speaking English "very well" or "well." Unfortunately, the language information available in the Canadian census is not directly comparable. In the Canadian data, we define individuals as fluent in the destination country language if they are able to conduct a conversation in either English or French. ${ }^{11}$

Given these definitions, Table 4 reports for each destination country the percent of immigrant men who are fluent in the destination country language, by five-year arrival cohorts. ${ }^{12}$ In all three destination countries, immigrant fluency rates rise monotonically with the length of time since arrival. This pattern is largely due to the fact that immigrants who do not speak the destination country language when they arrive tend to acquire fluency over time as they adapt to their new home. We must caution, however, that differences between immigrant arrival cohorts observed at a single point in time may reflect permanent differences between these cohorts as well as the changes that occur for a given cohort as it spends more time in the destination country. ${ }^{13}$

\footnotetext{
${ }^{11}$ In their study of immigrants to Canada and the United States, Duleep and Regets (1992) use these same definitions in an attempt to create roughly comparable measures of language fluency from the 1981 Canadian census and the 1980 U.S. census.

${ }^{12}$ The intervals listed in Table 4 (and in subsequent tables) for the immigrant arrival cohorts are those that pertain to the Australian and Canadian data; the slightly different immigrant cohorts that pertain to the U.S. data are as follows: pre-1970, 1970-74, 1975-79, 1980-84, and 1985-90. For ease of exposition, henceforth we will refer to particular immigrant cohorts using the year intervals that pertain to the Australian and Canadian data, with the implied understanding that in the U.S. data the actual cohort intervals begin and end one year earlier.

${ }^{13}$ By tracking cohorts of U.S. immigrants between the 1980 and 1990 censuses, Carliner $(1995,1996)$ and Funkhouser (1996) show that English proficiency does indeed improve markedly with duration of U.S. residence and that this improvement plays an important role in immigrant wage growth.
} 
For every arrival cohort, fluency rates are lower for U.S. immigrants than for Australian and Canadian immigrants, and the fluency deficit of U.S. immigrants is particularly large for cohorts arriving after 1970. For example, among the most recent immigrants (those arriving within five years of the census), only 61 percent of U.S. immigrants are fluent, as compared to 82 percent of Australian immigrants and 91 percent of Canadian immigrants. Even among immigrants who have spent $15-20$ years in the destination country (1971-75 arrivals), the fluency rate of U.S. immigrants (80 percent) is well below that of Australian immigrants (93 percent) and Canadian immigrants (97 percent). Given the substantial weight that the immigration point systems used in Australia and Canada have typically placed on language skills, these data seem to indicate that the Australian and Canadian point systems have been effective at tilting the immigration flow towards those proficient in the language of the destination country. In Table 4, the relative fluency of Canadian immigrants is probably overstated because of the particular wording of the language questions asked in the Canadian census. Recall, however, that the virtually identical language questions asked in the Australian and U.S. censuses produce fluency measures for these two countries that are directly comparable to each other. Moreover, the sheer magnitude of the fluency deficit observed for U.S. immigrants suggests that at least a portion of this deficit is real.

To learn more about the source of the fluency deficit for U.S. immigrants, Table 5 reports fluency rates separately by immigrant region of birth. ${ }^{14}$ In this table, we limit the sample to immigrants have been in the destination country for ten years or less. The fluency rates for Canadian immigrants are generally much higher than those observed for immigrants in the other two countries, but once again these high rates may well be an artifact of the way that fluency is measured in the Canadian data. More interesting and informative is the comparison between Australia and the United States. Fluency rates are quite similar for Australian and U.S. immigrants who come from the same source region. The last two rows of Table 5 show that the overall fluency rate for U.S. immigrants ( 65 percent) falls well short of the Australian rate ( 80 percent) almost entirely because the United States is home to a

\footnotetext{
${ }^{14}$ In Table 5, we exclude immigrants from the four source regions listed in Table 3 that cannot be defined for all three destination countries. The excluded regions are the following: United States, Other North America, Oceania/Antarctica, and Other.
} 
large population of Latin American immigrants who tend to speak English poorly. When we exclude immigrants from Central and South America, the U.S fluency rate jumps to 79 percent, whereas the Australian fluency rate rises only very slightly to 81 percent.

\section{Education}

The second immigrant skill measure we analyze is education. Table 6 reports the results of least squares regressions in which the dependent variable is years of schooling and the independent variables include dummies identifying immigrants from various arrival cohorts. ${ }^{15}$ The samples for these regressions include natives as well as immigrants. In the columns labeled (1), no other independent variables are included in the regressions, so the intercepts represent the average education level of natives in each destination country, and the coefficients on the immigrant cohort dummies show the education differentials between immigrants of each arrival cohort and natives. U.S. natives display the highest mean education level, 13.4 years, followed by Canadian natives with 12.6 years and Australian natives with 12.3 years. ${ }^{16}$ U.S. immigrants, however, have substantially lower levels of educational attainment than U.S. natives, with the deficit ranging between one and two years, depending on the arrival cohort. This contrasts with Australian and Canadian immigrants, who tend to have more schooling than natives in their respective destinations. The education levels of U.S. immigrants are low not just relative to U.S. natives, but also when compared directly with those of other immigrants. For all cohorts arriving after 1970, immigrants to Australia or Canada average at least a year more schooling than do U.S. immigrants from the same cohort.

The columns labeled (2) in Table 6 present education regressions that also include dummy variables identifying five-year age groups, with the dummy for ages 25-29 omitted. In these regressions, the intercepts now represent the average education level of 25-29 yearold natives, the immigrant cohort coefficients measure immigrant-native differences after conditioning on age, and the coefficients on the age dummies reflect education differentials between each age group and 25-29 year-olds. The age coefficients capture the secular rise in

\footnotetext{
${ }^{15}$ All of the regression tables presented in the paper report robust standard errors in parentheses.

${ }^{16}$ This pattern of education differences across the three countries is similar to what Evans, Kelley, and Wanner (1998) and Reitz (1998) report.
} 
schooling levels that took place over this period, particularly in Canada, where average educational attainment is sharply higher for those born after 1940. Controlling for age, however, has little effect on the estimated immigrant-native schooling differentials or on the conclusion that the United States is less successful than Australia and Canada at attracting well-educated immigrants.

Table 7 shows immigrant educational attainment by region of birth for post-1980/81 arrivals. The first three columns report average years of schooling for each immigrant group. Among immigrants from a particular source region, the education level of U.S. immigrants typically matches or exceeds that of Australian and Canadian immigrants, yet on the whole U.S. immigrants average about a year and a half less schooling than immigrants in the other two destination countries. As was the case with language fluency, the explanation for this pattern is the large immigration flow from Latin America to the United States. U.S. immigrants from Central and South America average less than ten years of schooling, and excluding this group from the calculations causes the mean education level of U.S. immigrants to shoot up from 11.7 years to 13.9 years. Considering only those who originate from outside of Latin America, U.S. immigrants average half a year more schooling than immigrants to Australia and Canada.

Because of differences across countries in educational practices and in the census questions used to elicit information about educational attainment, the years of schooling variable we have constructed may suffer from comparability problems. To a large extent, however, we would expect such factors to impact measured schooling in similar ways for immigrants and natives in the same destination country. It is therefore useful to examine a measure of immigrant education that is defined relative to the education level of natives in the destination country, because in this way we may be able to mitigate biases from countryspecific idiosyncrasies in the measurement of schooling levels. The last three columns of Table 7 report a relative education measure, here defined as the difference in average years of schooling between a particular immigrant group and natives in the same destination country. Because of the relatively high education level of U.S. natives, by this measure U.S. immigrants remain somewhat less educated than Australian and Canadian immigrants even after we exclude those originating from Latin America. In particular, considering only immigrants who arrived after 1980/81 and who were not born in Latin America, Australian 
immigrants average a year more schooling than Australian natives and Canadian immigrants average three-quarters of a year more schooling than Canadian natives. The relative education advantage for U.S. immigrants of one-half year is smaller than the corresponding education advantages observed for Australian and Canadian immigrants, but note that including Latin American immigrants in the calculation results in U.S. immigrants averaging 1.68 years less schooling than U.S. natives. Regardless of whether immigrant education levels are measured in absolute terms or relative to natives, the educational gap between U.S. immigrants and immigrants in the other two destination countries arises primarily because the United States receives a large flow of poorly-educated immigrants from Latin America.

Tables 6 and 7 provide information about average schooling levels. Immigration point systems like those used in Australia and Canada might be particularly effective at screening out immigrants from the bottom tail of the education distribution. In our data, however, the patterns evident at low education levels are similar to those just described for average education levels. For example, among immigrants arriving after 1980/81, the share with ten or fewer years of schooling is 15.8 percent in Australia, 15.7 percent in Canada, and 29.9 percent in the United States. ${ }^{17}$ Excluding immigrants from Latin America barely affects the Australian and Canadian calculations but drops the share for U.S. immigrants to 13.8 percent. Once immigrants from Latin America are excluded, U.S. immigrants are less likely than Australian and Canadian immigrants to possess low levels of schooling.

\section{Income}

The final immigrant skill measure we analyze is personal income. Ideally, we would prefer to use data on earnings rather than income, but the Australian census does not distinguish earnings from other income sources. ${ }^{18}$ To increase the correspondence between income and earnings, we now restrict the samples to employed men. ${ }^{19}$ The Australian data report employment during the census survey week and "usual" weekly income, whereas the

\footnotetext{
${ }^{17}$ The corresponding shares among natives are 32.2 percent in Australia, 21.1 percent in Canada, and 8.1 percent in the United States.

${ }^{18}$ Earnings information is available in the Canadian and U.S. censuses, however, and for these two countries we have replicated the analyses reported below using earnings rather than income as the dependent variable. The income and earnings regressions produce similar results.

${ }^{19}$ In the Canadian sample, we also exclude immigrants who arrived during the census year (1991), because income data are not available for these recent arrivals.
} 
Canadian and U.S. data on employment and income refer to the calendar year preceding the census. The Canadian and U.S. income data have been converted to a weekly basis so as to match the Australian data. ${ }^{20}$

Tables 8 and 9 present estimates from least squares regressions in which the dependent variable is the natural logarithm of weekly personal income, and the samples pool immigrant and native men. Two specifications are reported for each destination country. In the first specification, the independent variables include immigrant arrival cohort dummies, age dummies, controls for geographic location, and indicators for hours worked during the census survey week. The coefficients of the geographic location and weekly hours of work variables are restricted to be the same for immigrants and natives, whereas the coefficients of the age dummies are allowed to vary by nativity. The second specification adds as regressors years of schooling and indicators for fluency in the language of the destination country, and here the return to education can vary by nativity.

Table 8 reports the immigrant cohort coefficients from these regressions. These coefficients have been normalized to represent immigrant-native income differentials for men who are aged 25-29 (in both specifications) and who have 12 years of schooling (in specification (2)). Table 9 reports the coefficients of the age, education, and fluency variables. Note that the interactions between nativity and age in these regressions imply that the immigrant-native income gaps presented in Table 8 for ages 25-29 will differ at older ages.

Figure 1 provides a convenient way of summarizing the immigrant-native income differentials implied by these regressions. Based on the specification that does not control for education and fluency, the top panel of Figure 1 shows the predicted log income differentials between immigrant and native men, by destination country and immigrant arrival cohort. ${ }^{21}$ The bottom panel of Figure 1 is the same as the top panel, except that the

\footnotetext{
${ }^{20}$ Another difference between the income measures available for each country is that the Australian census reports income in fourteen intervals, whereas the Canadian and U.S. censuses provide continuous measures of income. For Australia, we use the midpoints of the reported income intervals to construct the income variable employed in our regressions. For Canada and the United States, the results reported here employ a continuous income variable, but we obtain similar results when we instead group these data into intervals and assign midpoints so as to mimic the Australian data.

${ }^{21}$ To control for age differences, both across countries and between immigrants and natives within a country, these calculations assign the same age distribution to all groups. In particular, we use the age distribution observed for our sample of U.S. immigrants: 20.2 percent are in the $25-29$ age range, 20.7 percent are $30-34,17.5$ percent are $35-39$, 14.8
} 
bottom panel is based on the regression specification that adds controls for education and fluency. ${ }^{22}$ In other words, the top panel of Figure 1 corresponds to specification (1) in Tables 8 and 9, whereas the bottom panel of the figure corresponds to specification (2).

A word of caution is in order about interpreting these graphs. Because analyses of immigrant outcomes using a single cross section of data cannot distinguish assimilation and cohort effects, the plots do not portray the life-cycle trajectories of immigrants as they gain experience in the destination country labor market. Instead, the graphs are only intended to illustrate the income differences between immigrants of various arrival cohorts and natives at a given point in time.

Figures 1 tells an interesting story. Without controlling for education and fluency, the income disadvantage of immigrants relative to natives is most severe in the United States and smallest in Australia, with Canada falling in between (see the top panel of Figure 1). Once we condition on education and fluency, however, immigrant-native income differentials for the United States shrink dramatically, with the U.S. differentials now smaller than those observed in Canada and sometimes even Australia (see the bottom panel of Figure 1). For example, without controls for education and fluency, immigrants who have been in the destination country for 11-15 years (i.e., 1976-80 arrivals) possess income deficits relative to natives of 7.6 percent in Australia, 15.9 percent in Canada, and 32.3 percent in the United States. After controlling for education and fluency, the corresponding income deficits are 2.4 percent for Australian immigrants, 7.5 percent for Canadian immigrants, and 2.7 percent for U.S. immigrants. The comparison between the top and bottom panels of Figure 1 suggests that the smaller income deficits (relative to natives) observed for Australian and Canadian immigrants than for U.S. immigrants are largely explained by the higher levels of education and fluency possessed by Australian and Canadian immigrants. Indeed, after conditioning on these observable skill measures, the relative incomes of U.S. immigrants compare favorably with those of Canadian immigrants for all arrival cohorts, and they compare favorably with those of Australian immigrants for cohorts that have been in the

percent are 40-44, 11.2 percent are 45-49, 9.0 percent are 50-54, and 6.7 percent are 55-59. Because the immigrant-native income differentials estimated for each country are allowed to vary by age group, the overall differentials shown in Figure 1 depend on the particular age distribution used. However, similar patterns emerge from using the age distributions observed for any of the immigrant or native samples in our three destination countries.

${ }^{22}$ The calculations displayed in the bottom panel of Figure 1 pertain to individuals with 12 years of education. 
destination country for more than ten years.

In Australia, immigrant-native income differences are relatively small to begin with and essentially disappear after controlling for education and fluency. Consistent with previous research, the Australian data show little correlation between an immigrant's income and his year of arrival. ${ }^{23}$ In addition, Table 9 indicates that Australian immigrants earn the same return to education as Australian natives, whereas the Canadian and U.S. data show the expected pattern of a lower return to education for immigrants. ${ }^{24}$ Evidently, both in terms of the intercept and the return to education, the wage structure is similar for immigrants and natives in Australia.

Tables 10 and 11 and Figure 2 replicate the preceding analysis of immigrant-native income differentials, but now using samples from each country that exclude immigrants born in Central and South America. With respect to comparisons of the relative incomes of immigrants in the three destination countries, notice that the top panel of Figure 2 resembles the bottom panel of Figure 1. Excluding Latin American immigrants (Figure 2) dramatically shrinks immigrant-native income differentials in the United States, resulting in income gaps for U.S. immigrants that are smaller than those of Canadian immigrants and some groups of Australian immigrants. With Latin American immigrants included in the samples (Figure 1), recall that controlling for education and fluency generated this same general pattern of results. Given our earlier findings that unskilled immigration from Latin America explains why U.S. immigrants overall have lower levels of education and English fluency than Australian and Canadian immigrants, it is not surprising that the impact of excluding Latin American immigrants on immigrant-native income differentials in the three countries is similar to the impact of controlling for education and fluency.

\footnotetext{
${ }^{23}$ Borjas (1988) reports this result in his analysis of data from the 1981 Australian census. McDonald and Worswick (1999) analyze microdata from the Australian Income Distribution Surveys of 1982, 1986, and 1990. They find little evidence of statistically significant cohort and assimilation effects on the earnings of Australian immigrants.

${ }^{24}$ The standard interpretation of this pattern is that schooling acquired by immigrants in their home country transfers imperfectly to the destination country's labor market (Chiswick 1978). The failure of the Australian data to conform to the expected pattern may be due in part to the limited information about educational attainment available in the census. Analyzing unique data with detailed information about the types of education obtained and how much of this education was obtained abroad and how much was obtained in Australia, Chapman and Iredale (1993) find that Australian immigrants are paid a higher wage premium for schooling received in Australia than for foreign schooling.
} 


\section{Conclusion}

Census data for 1990/91 indicate that Australian and Canadian immigrants have higher levels of English fluency, education, and income (relative to natives) than do U.S. immigrants. This skill deficit for U.S. immigrants arises primarily because the United States receives a much larger share of immigrants from Latin America than do the other two countries.

In his analysis of earlier census data for Canada and the United States, Borjas reports a similar finding: "Differences in the national-origin mix of immigrants arriving in Canada and the United States since 1965 are mainly responsible for the higher average skills and relative wages of immigrants in Canada" (Borjas 1993, p. 35). The large U.S. immigration flow from Latin America plays a leading role in this story, although not quite as dominant a role in Borjas's version of the story as it does in ours. ${ }^{25}$ From his analysis, Borjas concludes that the Canadian "point system works because it alters the national-origin mix of immigrant flows" (Borjas 1993, p. 40).

We do not believe, however, that our analysis provides much support for the proposition that the skills of U.S. immigrants would improve if the United States were to adopt an immigration point system similar to those in Australia and Canada. For several reasons, we strongly suspect that the Australian and Canadian point systems are not the primary reason that these countries receive few Latin American immigrants relative to the United States. First of all, the United States shares a long border and a long history with Mexico, and these factors undoubtedly contribute to the large presence of Latin American immigrants in the United States. Second, Australia and Canada never received many immigrants from Latin America, even before immigration point systems were introduced in Australia in the 1970s and Canada in the late 1960s (see Reitz 1998, Table 1.1, pp. 10-12). Finally, much of U.S. immigration from Latin America is undocumented (Warren and Passel 1987; Woodrow and Passel 1990) and subject to limited official control (Bean, Espenshade, White, and Dymowski 1990; Donato, Durand, and Massey 1992; Kossoudji 1992). A point system that screens legal immigrants for skills may do little to raise the skills or restrict the

\footnotetext{
${ }^{25}$ See footnote 10 of Borjas (1993).
} 
entry of Latin American immigrants to the United States, because these immigrants seem to find it relatively easy to enter outside of the official admissions system. 


\section{References}

Australian Department of Immigration, Local Government and Ethnic Affairs (ADILGEA) (1991). Efficiency Audit, Department of Immigration, Local Government and Ethnic Affairs, Audit Report No. 11, 1991 - 1992. Canberra: Australian Government Printing Service.

Bean, Frank D.; Espenshade, Thomas J.; White, Michael J.; and Dymowski, Robert F. "Post-IRCA Changes in the Volume and Composition of Undocumented Migration to the United States: An Assessment Based on Apprehensions Data." In Undocumented Migration to the United States: IRCA and the Experience of the 1980 , edited by Frank D. Bean, Barry Edmonston, and Jeffrey S. Passel. Washington, DC: Urban Institute Press, 1990, pp. 111-58.

Borjas, George J. International Differences in the Labor Market Performance of Immigrants. Kalamazoo, Mich.: W.E. Upjohn Institute for Employment Research, 1988.

. "Immigration and Self-Selection." In Immigration, Trade, and the Labor Market, edited by John M. Abowd and Richard B. Freeman. Chicago: University of Chicago Press, 1991, pp. 29-76.

- "Immigration Policy, National Origin, and Immigrant Skills: A Comparison of Canada and the United States." In Small Differences That Matter: Labor Markets and Income Maintenance in Canada and the United States, edited by David Card and Richard B. Freeman. Chicago: University of Chicago Press, 1993, pp. 21-43.

"Assimilation and Changes in Cohort Quality Revisited: What Happened to Immigrant Earnings in the 1980s?" Journal of Labor Economics, April 1995, 13(2), pp. 201-45.

Boyd, Monica. "Immigration Policies and Trends: A Comparison of Canada and the United States.” Demography, February 1976, 18(1), pp. 83-104.

Bureau of Immigration Research, Statistics Section. (1991). Settler Arrivals 1989-1990, Statistical Report No. 3. Canberra: Australian Government Printing Service.

Briggs, Vernon M., Jr. (1984). Immigration Policy and the American Labor Force. Baltimore: The Johns Hopkins University Press.

Card, David, and Freeman, Richard B., editors. Small Differences That Matter: Labor Markets and Income Maintenance in Canada and the United States. Chicago: University of Chicago Press, 1993.

Carliner, Geoffrey. "The Language Ability of U.S. Immigrants: Assimilation and Cohort Effects." Working Paper 5222. Cambridge, MA: NBER, 1995. 
. "The Wages and Language Skills of U.S. Immigrants." Working Paper 5763. Cambridge, MA: NBER, 1996.

Chapman, Bruce J., and Iredale, Robyn R. "Immigrant Qualifications: Recognition and Relative Wage Outcomes.” International Migration Review, Summer 1993, 27(2), pp. 359-87.

Chiswick, Barry R. "The Effect of Americanization on the Earnings of Foreign-Born Men." Journal of Political Economy, October 1978, 86(5), pp. 897-921.

(1987). "Immigration Policy, Source Countries, and Immigrant Skills: Australia, Canada, and the United States" in The Economics of Immigration. Proceedings of Conference held at the Australian National University. Canberra: Australian Government Printing Service.

Cobb-Clark, Deborah A. (1990). Immigrant Selectivity: The Roles of Household Structure and U.S. Immigration Policy. PhD dissertation, Economics Department, University of Michigan. Ann Arbor: University of Michigan.

Donato, Katharine M.; Durand, Jorge; and Massey, Douglas S. "Stemming the Tide? Assessing the Deterrent Effects of the Immigration Reform and Control Act." Demography, May 1992, 29(2), pp. 139-157.

Duleep, Harriet Orcutt and Mark C. Regets (1992). "Some Evidence on the Effects of Admissions Criteria on Immigrant Assimilation" in Immigration, Language and Ethnic Issues: Canada and the United States. Barry R. Chiswick, editor. Washington: American Enterprise Institute: 410 - 439.

Employment and Immigration Canada. (1992). Immigration Statistics 1991. Quebec: Employment and Immigration Canada.

Evans, M.D.R.; Kelley, Jonathan; and Wanner, Richard A. "The Consequences of Divorce for Children's Education: Australia, Canada, and the U.S.A., 1940-1990.” Manuscript. Canberra, Australia: Australian National University, 1998.

Freeman, Richard B., and Katz, Lawrence F. "Rising Wage Inequality: The United States Vs. Other Advanced Countries." In Working Under Different Rules, edited by Richard B. Freeman. New York: Russell Sage Foundation, 1994, pp. 29-62.

Funkhouser, Edward. "How Much of Immigrant Wage Assimilation is Related to English Language Acquisition?" Manuscript. Santa Barbara, CA: University of California, 1996.

Green, Alan. G. (1995). "A Comparison of Canadian and US Immigration Policy in the 
Twentieth Century" in Diminishing Returns: The Economics of Canada's Recent Immigration Policy. D. J. DeVortez, editor. Toronto and Vancouver: C.D. Howe Institute and The Laurier Institution.

Green, Alan G. and David A. Green. (1995). "Canadian Immigration Policy: The Effectiveness of the Point System and Other Instruments." Canadian Journal of Economics 28(4b): 1006 - 1041.

Gregory, Robert G., and Daly, Anne E. "Welfare and Economic Progress of Indigenous Men of Australia and the U.S., 1980-1990." Manuscript. Canberra, Australia: Australian National University, 1994.

Jasso, Guillermina and Mark R. Rosenzweig (1995). "Do Immigrants Screened for Skills Do Better than Family Reunification Immigrants?" International Migration Review 29(1): $85-111$.

Kossoudji, Sherrie A. "Playing Cat and Mouse at the U.S.-Mexican Border." Demography, May 1992, 29(2), pp. 159-80.

Lack, John and Jacqueline Templeton. (1995). Bold Experiment: A Documentary History of Australian Immigration Since 1945. Melbourne: Oxford University Press.

McDonald, James T., and Worswick, Christopher. "The Earnings of Immigrant Men in Australia: Assimilation, Cohort Effects, and Macroeconomic Conditions." Economic Record, March 1999, 75(228), pp. 49-62.

Price, Charles. "Australia." In The Politics of Migration Policies, edited by Daniel Kubat. New York: Center for Migration Studies, 1979, pp. 3-18.

Reimers, David M., and Troper, Harold. (1992). "Canadian and American Immigration Policy since 1945" in Immigration, Language and Ethnic Issues: Canada and the United States. Barry R. Chiswick, editor. Washington: American Enterprise Institute, $15-54$.

Reitz, Jeffrey G. Warmth of the Welcome : The Social Causes of Economic Success for Immigrants in Different Nations and Cities. Boulder, Colo.: Westview Press, 1998.

Statistics Canada, Housing, Family, and Social Statistics Division (1990). Immigrants in Canada: Selected Highlights. Ottawa: Canadian Government Printing Centre.

U.S. Department of Justice, Immigration and Naturalization Service. (1991). 1990 Statistical Yearbook of the Immigration and Naturalization Service. Washington: U.S. Government Printing Office. 
Vialet, Joyce C. (1989). Immigration: Numerical Limits and the Preference System. Washington: Congressional Research Service, Library of Congress.

Vialet, Joyce C. and Larry M. Eig. (1990). Immigration Act of 1990 (P.L. 101-649). Washington: Congressional Research Service, Library of Congress.

Warren, Robert, and Passel, Jeffrey S. 1987. "A Count of the Uncountable: Estimates of Undocumented Aliens Counted in the 1980 United States Census." Demography, August 1987, 24(3), pp. 375-93.

Wright, Robert E., and Maxim, Paul S. "Immigration Policy and Immigrant Quality: Empirical Evidence from Canada." Journal of Population Economics, November 1993, 6(4), pp. 337-52.

Woodrow, Karen A., and Jeffrey S Passel. "Post-IRCA Undocumented Immigration to the United States: An Assessment Based on the June 1988 CPS." In Undocumented Migration to the United States: IRCA and the Experience of the 1980s, edited by Frank D. Bean, Barry Edmonston, and Jeffrey S. Passel. Washington, DC: Urban Institute Press, 1990, pp. 33-72. 


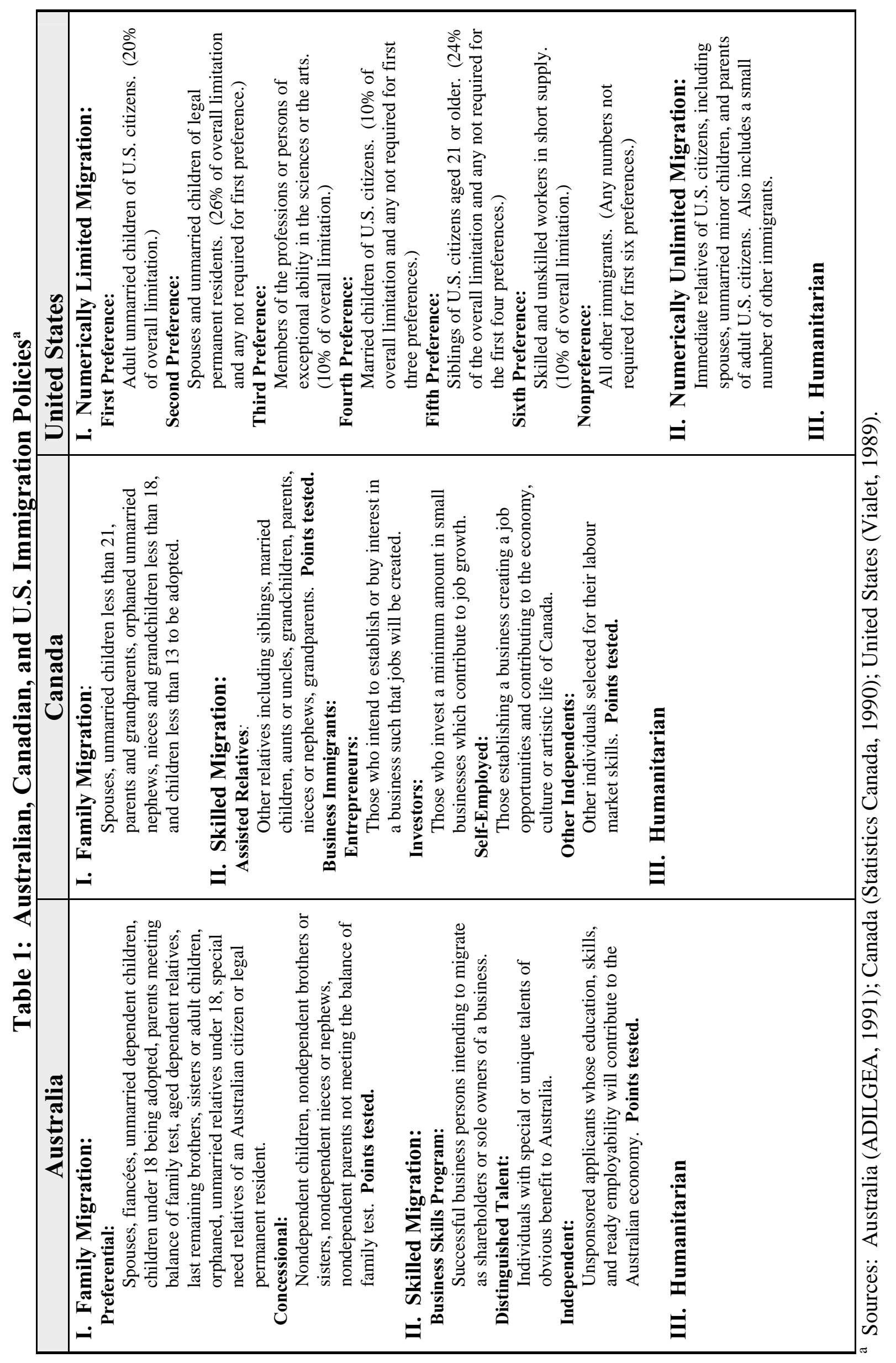


Table 2: Australian, Canadian, and U.S. Legal Immigrants by Region of Origin and Broad Class of Admissiona

\begin{tabular}{|l|r|r|r|r|r|}
\hline & $\begin{array}{c}\text { All } \\
\text { Regions }\end{array}$ & Asia & Europe & $\begin{array}{c}\text { Latin } \\
\text { America }^{\mathbf{b}}\end{array}$ & Africa \\
\hline Australia 1989/1990 & & & & & \\
Family & $24.8 \%$ & $29.0 \%$ & $23.3 \%$ & $15.8 \%$ & $15.5 \%$ \\
Skilled $^{\mathbf{c}}$ Refugee & $51.8 \%$ & $55.6 \%$ & $65.0 \%$ & $33.0 \%$ & $76.6 \%$ \\
Nonvisaed $^{\mathbf{d}}$ & $9.9 \%$ & $13.5 \%$ & $5.3 \%$ & $49.9 \%$ & $3.8 \%$ \\
All Immigrant Categories & $13.6 \%$ & $2.0 \%$ & $6.4 \%$ & $1.2 \%$ & $4.1 \%$ \\
$\quad$ Total Number of Immigrants & $100.0 \%$ & $100.0 \%$ & $100.0 \%$ & $100.0 \%$ & $100.0 \%$ \\
& 121,227 & 50,607 & 38,386 & 4,133 & 4,192 \\
Canada 1991 & & & & & \\
Family & & & & & \\
Skilled & $37.4 \%$ & $36.5 \%$ & $32.7 \%$ & $33.1 \%$ & $22.1 \%$ \\
Refugee & $39.4 \%$ & $46.1 \%$ & $40.0 \%$ & $20.3 \%$ & $34.1 \%$ \\
All Immigrant Categories & $23.1 \%$ & $17.5 \%$ & $27.3 \%$ & $46.5 \%$ & $43.8 \%$ \\
$\quad$ Total Number of Immigrants & $100.0 \%$ & $100.0 \%$ & $100.0 \%$ & $100.0 \%$ & $100.0 \%$ \\
& 230,781 & 119,955 & 48,055 & 23,986 & 16,087 \\
United States 1990 & & & & & \\
Family (Numerically Limited) & $32.7 \%$ & $33.0 \%$ & $13.0 \%$ & $44.7 \%$ & $20.7 \%$ \\
Family (Numerically Unlimited) & $35.3 \%$ & $32.6 \%$ & $31.4 \%$ & $39.7 \%$ & $47.7 \%$ \\
Skilled & $8.2 \%$ & $8.9 \%$ & $8.4 \%$ & $6.2 \%$ & $11.7 \%$ \\
Refugee & $14.8 \%$ & $17.1 \%$ & $34.1 \%$ & $4.7 \%$ & $11.3 \%$ \\
Other & $9.0 \%$ & $8.4 \%$ & $13.1 \%$ & $4.7 \%$ & $8.6 \%$ \\
All Immigrant Categories & $100.0 \%$ & $100.0 \%$ & $100.0 \%$ & $100.0 \%$ & $100.0 \%$ \\
$\quad$ Total Number of Immigrants & 656,111 & 303,217 & 97,108 & 218,163 & 19,524 \\
\hline
\end{tabular}

a Sources: Australia (Bureau of Immigration Research, 1991, Table 2); Canada (Employment and Immigration Canada, 1992, Table IM16); United States (U.S. Department of Justice, 1991, Tables 5 and 7).

b Includes Mexico, Central America, South America, and the Caribbean.

${ }^{c}$ Includes immigrants admitted under the Concessional Family Migration Program.

${ }^{d}$ Immigrants for whom no visa is required, including New Zealand citizens, special eligibility migrants, Australian children born overseas, and others.

e The U.S. figures reported here exclude those formerly undocumented migrants who were legalized under the amnesty provisions of the Immigration Reform and Control Act of 1986 (IRCA). 
Table 3

Region of Birth Distributions of Post-1980/81 Immigrant Arrivals

\begin{tabular}{|c|c|c|c|}
\hline \multirow[b]{2}{*}{ Region of Birth } & \multicolumn{3}{|c|}{ Destination Country } \\
\hline & Australia & Canada & United States \\
\hline United Kingdom & 18.9 & 4.9 & 2.1 \\
\hline Europe & 13.6 & 21.2 & 8.8 \\
\hline Middle East & 5.9 & 8.7 & 4.2 \\
\hline Africa & 4.0 & 8.2 & 3.8 \\
\hline China & 6.2 & 6.0 & 3.5 \\
\hline Hong Kong & 3.0 & 7.1 & 0.6 \\
\hline Philippines & 2.4 & 4.0 & 4.1 \\
\hline Southern Asia & 5.9 & 11.1 & 5.1 \\
\hline Other Asia & 18.6 & 11.3 & 14.3 \\
\hline Central/South America & 2.3 & 14.0 & 47.1 \\
\hline United States & 2.0 & 2.7 & n.a. \\
\hline Other North America & 0.7 & n.a. & 1.4 \\
\hline Oceania/Antarctica & 16.4 & n.a. & 0.6 \\
\hline Other & n.a. & 0.8 & 4.5 \\
\hline All Regions & $100.0 \%$ & $100.0 \%$ & $100.0 \%$ \\
\hline Sample Size & 3,315 & 10,148 & 114,754 \\
\hline
\end{tabular}

Note: Data are from the 1991 Australian and Canadian censuses and the 1990 U.S. census. The samples include foreign-born men ages 25-59 who immigrated during 1981-91 in the Australian and Canadian data or during 1980-90 in the U.S. data. Entries of "n.a." indicate regions of birth that cannot be defined for a particular destination country. Columns may not sum to 100 percent because of rounding error. Sampling weights were used in the U.S. calculations. 
Table 4

Percent of Immigrants Fluent in Destination Country Language, by Arrival Cohort

\begin{tabular}{|c|c|c|c|}
\hline \multirow[b]{2}{*}{ Immigrant Cohort } & \multicolumn{3}{|c|}{ Destination Country } \\
\hline & Australia & Canada & United States \\
\hline Pre-1971 Arrivals & $\begin{array}{c}94.9 \\
(0.3)\end{array}$ & $\begin{array}{l}98.8 \\
(0.1)\end{array}$ & $\begin{array}{l}91.0 \\
(0.1)\end{array}$ \\
\hline & {$[5,864]$} & {$[17,614]$} & {$[95,442]$} \\
\hline 1971-75 Arrivals & 93.3 & 97.4 & 79.8 \\
\hline & $\begin{array}{c}(0.7) \\
{[1,357]}\end{array}$ & $\begin{array}{c}(0.2) \\
{[6,371]}\end{array}$ & $\begin{array}{c}(0.2) \\
{[38,770]}\end{array}$ \\
\hline 1976-80 Arrivals & $\begin{array}{c}90.9 \\
(0.9) \\
{[972]}\end{array}$ & $\begin{array}{c}97.0 \\
(0.3) \\
{[4,424]}\end{array}$ & $\begin{array}{c}76.5 \\
(0.2) \\
{[48,056]}\end{array}$ \\
\hline 1981-85 Arrivals & $\begin{array}{c}86.7 \\
(1.0) \\
{[1,203]}\end{array}$ & $\begin{array}{c}95.5 \\
(0.3) \\
{[3,562]}\end{array}$ & $\begin{array}{c}69.5 \\
(0.2) \\
{[58,948]}\end{array}$ \\
\hline 1986-91 Arrivals & $\begin{array}{c}82.4 \\
(0.8) \\
{[2,099]}\end{array}$ & $\begin{array}{c}91.1 \\
(0.4) \\
{[6,599]}\end{array}$ & $\begin{array}{c}61.3 \\
(0.2) \\
{[55,808]}\end{array}$ \\
\hline
\end{tabular}

Note: Standard errors are in parentheses, and sample sizes are in brackets. Data are from the 1991 Australian and Canadian censuses and the 1990 U.S. census. The samples include foreign-born men ages 25-59. In the Australian and U.S. data, immigrants are designated as "fluent in the destination country language" if they speak only English or else report speaking English "very well" or "well." In the Canadian data, the corresponding measure of fluency identifies immigrants who can conduct a conversation in either English or French. The intervals listed above for the immigrant arrival cohorts are those defined in the Australian and Canadian data; the slightly different immigrant cohorts defined in the U.S. data are as follows: pre-1970, 197074, 1975-79, 1980-84, and 1985-90. Sampling weights were used in the U.S. calculations. 
Table 5

Percent of Post-1980/81 Immigrant Arrivals Fluent in Destination Country Language, by Birthplace

\begin{tabular}{|c|c|c|c|}
\hline \multirow[b]{2}{*}{ Region of Birth } & \\
\hline & Australia & Canada & United States \\
\hline \multirow[t]{2}{*}{ United Kingdom } & 100.0 & 100.0 & 99.7 \\
\hline & (.) & (.) & $(0.1)$ \\
\hline \multirow[t]{2}{*}{ Europe } & 75.3 & 89.7 & 77.6 \\
\hline & $(2.0)$ & $(0.7)$ & $(0.5)$ \\
\hline \multirow[t]{2}{*}{ Middle East } & 71.3 & 95.1 & 88.2 \\
\hline & $(3.2)$ & $(0.7)$ & $(0.5)$ \\
\hline \multirow[t]{2}{*}{ Africa } & 100.0 & 99.5 & 94.6 \\
\hline & (.) & $(0.2)$ & $(0.4)$ \\
\hline \multirow[t]{2}{*}{ China } & 53.9 & 70.0 & 55.5 \\
\hline & $(3.5)$ & $(1.9)$ & $(0.9)$ \\
\hline \multirow[t]{2}{*}{ Hong Kong } & 81.0 & 96.7 & 81.6 \\
\hline & $(3.9)$ & $(0.7)$ & $(1.5)$ \\
\hline \multirow[t]{2}{*}{ Philippines } & 98.7 & 99.5 & 94.4 \\
\hline & $(1.3)$ & $(0.3)$ & $(0.4)$ \\
\hline \multirow[t]{2}{*}{ Southern Asia } & 96.4 & 94.5 & 93.5 \\
\hline & $(1.4)$ & $(0.7)$ & $(0.4)$ \\
\hline \multirow[t]{2}{*}{ Other Asia } & 66.8 & 88.3 & 64.7 \\
\hline & $(1.9)$ & $(0.9)$ & $(0.4)$ \\
\hline \multirow[t]{2}{*}{ Central/South America } & 57.7 & 94.6 & 51.2 \\
\hline & $(5.9)$ & $(0.6)$ & $(0.2)$ \\
\hline \multirow[t]{2}{*}{ All Regions Listed Above } & 80.4 & 92.4 & 64.8 \\
\hline & $(0.7)$ & $(0.3)$ & $(0.2)$ \\
\hline All Regions, Excluding & 81.0 & 92.0 & 78.6 \\
\hline Central/South America & $(0.7)$ & $(0.3)$ & $(0.2)$ \\
\hline
\end{tabular}

Note: Standard errors are in parentheses. Data are from the 1991 Australian and Canadian censuses and the 1990 U.S. census. The samples include foreign-born men ages 25-59 who immigrated during 1981-91 in the Australian and Canadian data or during 1980-90 in the U.S. data. In the Australian and U.S. data, immigrants are designated as "fluent in the destination country language" if they speak only English or else report speaking English "very well" or "well." In the Canadian data, the corresponding measure of fluency identifies immigrants who can conduct a conversation in either English or French. Sampling weights were used in the U.S. calculations. 
Table 6

Education Regressions

\begin{tabular}{|c|c|c|c|c|c|c|}
\hline \multirow[b]{3}{*}{ Regressor } & \multicolumn{6}{|c|}{ Destination Country } \\
\hline & \multicolumn{2}{|c|}{ Australia } & \multicolumn{2}{|c|}{ Canada } & \multicolumn{2}{|c|}{ United States } \\
\hline & $(1)$ & (2) & (1) & (2) & $(1)$ & (2) \\
\hline Intercept (Natives) & $\begin{array}{l}12.29 \\
(0.02)\end{array}$ & $\begin{array}{c}12.18 \\
(0.03)\end{array}$ & $\begin{array}{l}12.56 \\
(0.01)\end{array}$ & $\begin{array}{c}12.96 \\
(0.01)\end{array}$ & $\begin{array}{l}13.39 \\
(0.01)\end{array}$ & $\begin{array}{c}13.24 \\
(0.03)\end{array}$ \\
\hline Immigrant Cohort: & & & & & & \\
\hline Pre-1971 Arrivals & $\begin{array}{c}0.07 \\
(0.04)\end{array}$ & $\begin{array}{c}0.09 \\
(0.04)\end{array}$ & $\begin{array}{l}-0.09 \\
(0.03)\end{array}$ & $\begin{array}{c}0.38 \\
(0.03)\end{array}$ & $\begin{array}{l}-0.99 \\
(0.02)\end{array}$ & $\begin{array}{l}-0.93 \\
(0.02)\end{array}$ \\
\hline 1971-75 Arrivals & $\begin{array}{c}0.10 \\
(0.07)\end{array}$ & $\begin{array}{c}0.10 \\
(0.07)\end{array}$ & $\begin{array}{c}0.43 \\
(0.05)\end{array}$ & $\begin{array}{c}0.50 \\
(0.05)\end{array}$ & $\begin{array}{l}-2.03 \\
(0.03)\end{array}$ & $\begin{array}{l}-2.10 \\
(0.03)\end{array}$ \\
\hline 1976-80 Arrivals & $\begin{array}{c}0.61 \\
(0.07)\end{array}$ & $\begin{array}{c}0.59 \\
(0.07)\end{array}$ & $\begin{array}{c}0.45 \\
(0.05)\end{array}$ & $\begin{array}{c}0.36 \\
(0.05)\end{array}$ & $\begin{array}{l}-1.97 \\
(0.03)\end{array}$ & $\begin{array}{l}-2.03 \\
(0.03)\end{array}$ \\
\hline 1981-85 Arrivals & $\begin{array}{c}0.49 \\
(0.07)\end{array}$ & $\begin{array}{c}0.47 \\
(0.07)\end{array}$ & $\begin{array}{c}0.63 \\
(0.06)\end{array}$ & $\begin{array}{c}0.49 \\
(0.06)\end{array}$ & $\begin{array}{l}-1.93 \\
(0.02)\end{array}$ & $\begin{array}{l}-1.96 \\
(0.02)\end{array}$ \\
\hline 1986-91 Arrivals & $\begin{array}{c}1.05 \\
(0.06)\end{array}$ & $\begin{array}{c}1.04 \\
(0.05)\end{array}$ & $\begin{array}{c}0.62 \\
(0.04)\end{array}$ & $\begin{array}{c}0.44 \\
(0.04)\end{array}$ & $\begin{array}{l}-1.37 \\
(0.03)\end{array}$ & $\begin{array}{l}-1.38 \\
(0.03)\end{array}$ \\
\hline Age Group: & & & & & & \\
\hline $30-34$ & & $\begin{array}{c}0.17 \\
(0.04)\end{array}$ & & $\begin{array}{l}-0.02 \\
(0.02)\end{array}$ & & $\begin{array}{c}0.17 \\
(0.04)\end{array}$ \\
\hline $35-39$ & & $\begin{array}{c}0.24 \\
(0.04)\end{array}$ & & $\begin{array}{c}0.03 \\
(0.02)\end{array}$ & & $\begin{array}{c}0.43 \\
(0.04)\end{array}$ \\
\hline $40-44$ & & $\begin{array}{c}0.22 \\
(0.04)\end{array}$ & & $\begin{array}{l}-0.13 \\
(0.02)\end{array}$ & & $\begin{array}{c}0.57 \\
(0.04)\end{array}$ \\
\hline $45-49$ & & $\begin{array}{c}0.07 \\
(0.05)\end{array}$ & & $\begin{array}{l}-0.61 \\
(0.03)\end{array}$ & & $\begin{array}{c}0.25 \\
(0.05)\end{array}$ \\
\hline $50-54$ & & $\begin{array}{c}0.01 \\
(0.05)\end{array}$ & & $\begin{array}{l}-1.45 \\
(0.03)\end{array}$ & & $\begin{array}{l}-0.25 \\
(0.05)\end{array}$ \\
\hline $55-59$ & & $\begin{array}{l}-0.15 \\
(0.06)\end{array}$ & & $\begin{array}{l}-2.11 \\
(0.03)\end{array}$ & & $\begin{array}{l}-0.57 \\
(0.06)\end{array}$ \\
\hline
\end{tabular}

Destination Country

Note: The dependent variable is years of schooling. The coefficients were estimated by least squares, and standard errors are shown in parentheses. Data are from the 1991 Australian and Canadian censuses and the 1990 U.S. census. The samples include men ages 25-59, with non-whites excluded from the native but not the foreign-born samples. The sample sizes for these regressions are 31,848 for Australia, 178,257 for Canada, and 340,073 for the United States. The intervals listed above for the immigrant arrival cohorts are those defined in the Australian and Canadian data; the slightly different immigrant cohorts defined in the U.S. data are as follows: pre-1970, 1970-74, 1975-79, 1980-84, and 1985-90. The reference group for the age dummies is 2529 year-olds. Sampling weights were used in the U.S. calculations. 
Table 7

Average Education of Post-1980/81 Immigrant Arrivals, by Birthplace

\begin{tabular}{|c|c|c|c|c|c|c|}
\hline \multirow[b]{2}{*}{ Region of Birth } & & \\
\hline & Australia & Canada & U.S. & Australia & Canada & U.S. \\
\hline \multirow[t]{2}{*}{ United Kingdom } & 13.09 & 14.36 & 14.94 & 0.80 & 1.81 & 1.56 \\
\hline & $(0.09)$ & $(0.10)$ & $(0.06)$ & $(0.09)$ & $(0.10)$ & $(0.06)$ \\
\hline \multirow[t]{2}{*}{ Europe } & 13.28 & 13.08 & 13.74 & 0.99 & 0.54 & 0.33 \\
\hline & $(0.11)$ & $(0.08)$ & $(0.04)$ & $(0.11)$ & $(0.08)$ & $(0.04)$ \\
\hline \multirow[t]{2}{*}{ Middle East } & 13.47 & 13.79 & 14.10 & 1.17 & 1.25 & 0.72 \\
\hline & $(0.21)$ & $(0.11)$ & $(0.05)$ & $(0.21)$ & $(0.11)$ & $(0.05)$ \\
\hline \multirow[t]{2}{*}{ Africa } & 13.46 & 13.89 & 14.67 & 1.17 & 1.34 & 1.29 \\
\hline & $(0.17)$ & $(0.10)$ & $(0.05)$ & $(0.17)$ & $(0.10)$ & $(0.05)$ \\
\hline \multirow[t]{2}{*}{ China } & 13.46 & 12.75 & 13.01 & 1.17 & 0.21 & -0.37 \\
\hline & $(0.16)$ & $(0.17)$ & $(0.08)$ & $(0.16)$ & $(0.17)$ & $(0.08)$ \\
\hline \multirow[t]{2}{*}{ Hong Kong } & 13.51 & 14.35 & 14.03 & 1.21 & 1.80 & 0.64 \\
\hline & $(0.22)$ & $(0.09)$ & $(0.14)$ & $(0.22)$ & $(0.09)$ & $(0.14)$ \\
\hline \multirow[t]{2}{*}{ Philippines } & 14.34 & 13.83 & 14.09 & 2.05 & 1.29 & 0.71 \\
\hline & $(0.13)$ & $(0.12)$ & $(0.04)$ & $(0.13)$ & $(0.12)$ & $(0.04)$ \\
\hline \multirow[t]{2}{*}{ Southern Asia } & 13.96 & 13.03 & 15.21 & 1.66 & 0.49 & 1.82 \\
\hline & $(0.18)$ & $(0.10)$ & $(0.05)$ & $(0.18)$ & $(0.10)$ & $(0.05)$ \\
\hline \multirow[t]{2}{*}{ Other Asia } & 13.07 & 11.94 & 13.12 & 0.78 & -0.60 & -0.27 \\
\hline & $(0.09)$ & $(0.11)$ & $(0.04)$ & $(0.09)$ & $(0.11)$ & $(0.04)$ \\
\hline \multirow[t]{2}{*}{ Central/South America } & 13.02 & 12.30 & 9.60 & 0.73 & -0.24 & -3.79 \\
\hline & $(0.23)$ & $(0.09)$ & $(0.02)$ & $(0.22)$ & $(0.09)$ & $(0.02)$ \\
\hline \multirow[t]{2}{*}{ All Regions Listed Above } & 13.31 & 13.13 & 11.70 & 1.01 & 0.59 & -1.68 \\
\hline & $(0.05)$ & $(0.03)$ & $(0.01)$ & $(0.05)$ & $(0.03)$ & $(0.01)$ \\
\hline All Regions, Excluding & 13.31 & 13.27 & 13.85 & 1.02 & 0.73 & 0.46 \\
\hline Central/South America & $(0.05)$ & $(0.04)$ & $(0.02)$ & $(0.05)$ & $(0.04)$ & $(0.02)$ \\
\hline
\end{tabular}

Note: Standard errors are in parentheses. Data are from the 1991 Australian and Canadian censuses and the 1990 U.S. census. The samples include men ages 25-59, with non-whites excluded from the native but not the foreign-born samples. The foreign-born samples are limited to men who immigrated during 1981-91 in the Australian and Canadian data or during 1980-90 in the U.S. data. Sampling weights were used in the U.S. calculations. 
Table 8

Income Regressions

Immigrant Cohort Coefficients

\begin{tabular}{|c|c|c|c|c|c|c|}
\hline \multirow[b]{2}{*}{ Regressor } & \multicolumn{2}{|c|}{ Australia } & \multicolumn{2}{|c|}{ Canada } & \multicolumn{2}{|c|}{ United States } \\
\hline & $(1)$ & $(2)$ & $(1)$ & $(2)$ & $(1)$ & $(2)$ \\
\hline \multicolumn{7}{|l|}{ Immigrant Cohort: } \\
\hline \multirow[t]{2}{*}{ Pre-1971 Arrivals } & -.018 & .019 & .079 & .039 & .009 & .148 \\
\hline & $(.019)$ & $(.019)$ & $(.015)$ & $(.015)$ & $(.011)$ & $(.013)$ \\
\hline \multirow[t]{2}{*}{ 1971-75 Arrivals } & -.030 & .018 & -.030 & -.044 & -.165 & .092 \\
\hline & $(.022)$ & $(.023)$ & $(.017)$ & $(.016)$ & $(.012)$ & $(.016)$ \\
\hline \multirow[t]{2}{*}{ 1976-80 Arrivals } & -.047 & -.009 & -.074 & -.069 & -.227 & .042 \\
\hline & $(.027)$ & $(.027)$ & $(.017)$ & $(.017)$ & $(.011)$ & $(.016)$ \\
\hline \multirow[t]{2}{*}{ 1981-85 Arrivals } & -.062 & .009 & -.142 & -.126 & -.361 & -.085 \\
\hline & $(.023)$ & $(.024)$ & $(.018)$ & $(.018)$ & $(.011)$ & $(.016)$ \\
\hline \multirow[t]{2}{*}{ 1986-91 Arrivals } & -.053 & .001 & -.438 & -.403 & -.529 & -.275 \\
\hline & $(.021)$ & $(.021)$ & $(.017)$ & $(.018)$ & $(.012)$ & $(.016)$ \\
\hline $\mathrm{R}^{2}$ & .113 & .169 & .115 & .160 & .210 & .289 \\
\hline Sample Size & 28,101 & 24,996 & 163,988 & 163,974 & 306,915 & 306,915 \\
\hline \multicolumn{7}{|l|}{ Control Variables: } \\
\hline Age Dummies & Yes & Yes & Yes & Yes & Yes & Yes \\
\hline Education & No & Yes & No & Yes & No & Yes \\
\hline Fluency Dummies & No & Yes & No & Yes & No & Yes \\
\hline
\end{tabular}

Note: The dependent variable is the natural logarithm of weekly personal income. The coefficients were estimated by least squares, and standard errors are shown in parentheses. Data are from the 1991 Australian and Canadian censuses and the 1990 U.S. census. The samples include men ages 25-59, with non-whites excluded from the native but not the foreign-born samples. Only employed men are included in the samples. In addition to the control variables listed above, all regressions include indicators for geographic location and hours worked during the census survey week. The coefficients of the controls for geographic location, weekly hours of work, and fluency are restricted to be the same for immigrants and natives, whereas the coefficients of the age and education variables are allowed to vary by nativity. The intervals listed above for the immigrant arrival cohorts are those defined in the Australian and Canadian data; the slightly different immigrant cohorts defined in the U.S. data are as follows: pre-1970, 1970-74, 1975-79, 1980-84, and 1985-90. The immigrant cohort coefficients reported in this table have been normalized to represent immigrant-native income differentials for men who are aged 25-29 (in both specifications) and who have 12 years of education (in specification (2)). Sampling weights were used in the U.S. calculations. 
Table 9

Income Regressions

Age, Education, and Fluency Coefficients

Destination Country

\begin{tabular}{|c|c|c|c|c|c|c|}
\hline \multirow[b]{2}{*}{ Regressor } & & & \\
\hline & $(1)$ & (2) & $(1)$ & (2) & $(1)$ & (2) \\
\hline \multicolumn{7}{|l|}{ Age Group: } \\
\hline \multirow[t]{2}{*}{$30-34$} & .112 & .095 & .255 & .237 & .235 & .222 \\
\hline & $(.012)$ & $(.012)$ & $(.007)$ & $(.007)$ & $(.013)$ & $(.013)$ \\
\hline \multirow[t]{2}{*}{$35-39$} & .137 & .120 & .374 & .351 & .374 & .335 \\
\hline & $(.013)$ & $(.013)$ & $(.007)$ & $(.007)$ & $(.013)$ & $(.013)$ \\
\hline \multirow[t]{2}{*}{$40-44$} & .173 & .169 & .448 & .436 & .497 & .441 \\
\hline & $(.014)$ & $(.014)$ & $(.007)$ & $(.007)$ & $(.014)$ & $(.013)$ \\
\hline \multirow[t]{2}{*}{$45-49$} & .168 & .194 & .469 & .489 & .555 & .524 \\
\hline & $(.015)$ & $(.016)$ & $(.008)$ & $(.008)$ & $(.015)$ & $(.015)$ \\
\hline \multirow[t]{2}{*}{$50-54$} & .121 & .153 & .452 & .520 & .580 & .586 \\
\hline & $(.017)$ & $(.017)$ & $(.009)$ & $(.009)$ & $(.017)$ & $(.016)$ \\
\hline \multirow[t]{2}{*}{$55-59$} & .013 & .050 & .424 & .527 & .580 & .601 \\
\hline & $(.020)$ & $(.022)$ & $(.010)$ & $(.010)$ & $(.018)$ & $(.017)$ \\
\hline \multicolumn{7}{|l|}{ Immigrant $\times$ Age Group: } \\
\hline \multirow[t]{2}{*}{$30-34$} & -.046 & -.036 & -.108 & .010 & -.059 & -.061 \\
\hline & $(.023)$ & $(.023)$ & $(.017)$ & $(.018)$ & $(.014)$ & $(.014)$ \\
\hline \multirow[t]{2}{*}{$35-39$} & -.009 & .010 & -.104 & .012 & -.078 & -.052 \\
\hline & $(.025)$ & $(.025)$ & $(.017)$ & $(.018)$ & $(.014)$ & $(.014)$ \\
\hline \multirow[t]{2}{*}{$40-44$} & -.013 & -.006 & -.084 & .015 & -.123 & -.073 \\
\hline & $(.025)$ & $(.025)$ & $(.017)$ & $(.017)$ & $(.015)$ & $(.015)$ \\
\hline \multirow[t]{2}{*}{$45-49$} & -.070 & -.053 & -.089 & -.012 & -.172 & -.113 \\
\hline & $(.027)$ & $(.028)$ & $(.018)$ & $(.018)$ & $(.017)$ & $(.016)$ \\
\hline \multirow[t]{2}{*}{$50-54$} & -.106 & -.071 & -.125 & -.048 & -.197 & -.150 \\
\hline & $(.030)$ & $(.031)$ & $(.019)$ & $(.019)$ & $(.019)$ & $(.018)$ \\
\hline \multirow[t]{2}{*}{$55-59$} & .026 & .056 & -.160 & -.096 & -.220 & -.153 \\
\hline & $(.033)$ & $(.037)$ & $(.021)$ & $(.021)$ & $(.019)$ & $(.019)$ \\
\hline \multirow[t]{2}{*}{ Education } & & .057 & & .065 & & .090 \\
\hline & & $(.002)$ & & $(.001)$ & & $(.002)$ \\
\hline \multirow[t]{2}{*}{ Immigrant $\times$ Education } & & -.004 & & -.024 & & -.031 \\
\hline & & $(.003)$ & & $(.001)$ & & $(.002)$ \\
\hline \multicolumn{7}{|l|}{$\begin{array}{l}\text { Ability to Speak English } \\
\text { (or French in Canada): }\end{array}$} \\
\hline \multirow[t]{2}{*}{ Well or Very Well } & & -.163 & & -.148 & & -.090 \\
\hline & & $(.013)$ & & $(.009)$ & & $(.015)$ \\
\hline Not at All or Not Well & & $\begin{array}{l}-.415 \\
(033)\end{array}$ & & $\begin{array}{l}-.187 \\
(030)\end{array}$ & & -.269 \\
\hline
\end{tabular}

Note: These coefficients are from the same income regressions reported in Table 8; see the note to that table for more information. Standard errors are shown in parentheses. The reference group for the age dummies is 25-29 year-olds. The reference group for the fluency dummies is men who speak only English in the Australian and U.S. data, and men who speak only English and/or French in the Canadian data. 
Table 10

Income Regressions, Excluding Immigrants from Central/South America

Immigrant Cohort Coefficients

\begin{tabular}{|c|c|c|c|c|c|c|}
\hline \multirow[b]{2}{*}{ Regressor } & \multicolumn{2}{|c|}{ Australia } & \multicolumn{2}{|c|}{ Canada } & \multicolumn{2}{|c|}{ United States } \\
\hline & $(1)$ & (2) & $(1)$ & $(2)$ & (1) & (2) \\
\hline \multicolumn{7}{|l|}{ Immigrant Cohort: } \\
\hline \multirow[t]{2}{*}{ Pre-1971 Arrivals } & -.020 & .017 & .073 & .037 & .078 & .125 \\
\hline & $(.019)$ & $(.019)$ & $(.016)$ & $(.016)$ & $(.012)$ & $(.013)$ \\
\hline \multirow[t]{2}{*}{ 1971-75 Arrivals } & -.033 & .013 & -.008 & -.009 & .003 & .099 \\
\hline & $(.023)$ & $(.023)$ & $(.018)$ & $(.018)$ & $(.013)$ & $(.017)$ \\
\hline \multirow[t]{2}{*}{ 1976-80 Arrivals } & -.049 & -.015 & -.062 & -.045 & -.089 & .010 \\
\hline & $(.028)$ & $(.028)$ & $(.018)$ & $(.018)$ & $(.013)$ & $(.018)$ \\
\hline \multirow[t]{2}{*}{ 1981-85 Arrivals } & -.063 & .006 & -.128 & -.099 & -.240 & -.115 \\
\hline & $(.023)$ & $(.024)$ & $(.020)$ & $(.020)$ & $(.013)$ & $(.018)$ \\
\hline \multirow[t]{2}{*}{ 1986-91 Arrivals } & -.051 & .002 & -.440 & -.388 & -.381 & -.281 \\
\hline & $(.021)$ & $(.021)$ & $(.019)$ & $(.019)$ & $(.013)$ & $(.018)$ \\
\hline $\mathrm{R}^{2}$ & .113 & .168 & .113 & .159 & .198 & .273 \\
\hline Sample Size & 27,959 & 24,892 & 160,147 & 160,133 & 183,193 & 183,193 \\
\hline \multicolumn{7}{|l|}{ Control Variables: } \\
\hline Age Dummies & Yes & Yes & Yes & Yes & Yes & Yes \\
\hline Education & No & Yes & No & Yes & No & Yes \\
\hline Fluency Dummies & No & Yes & No & Yes & No & Yes \\
\hline
\end{tabular}

Note: The dependent variable is the natural logarithm of weekly personal income. The coefficients were estimated by least squares, and standard errors are shown in parentheses. Data are from the 1991 Australian and Canadian censuses and the 1990 U.S. census. The samples include men ages 25-59, with non-whites excluded from the native but not the foreign-born samples. Only employed men are included in the samples. These particular regressions exclude immigrants born in Central and South America. In addition to the control variables listed above, all regressions include indicators for geographic location and hours worked during the census survey week. The coefficients of the controls for geographic location, weekly hours of work, and fluency are restricted to be the same for immigrants and natives, whereas the coefficients of the age and education variables are allowed to vary by nativity. The intervals listed above for the immigrant arrival cohorts are those defined in the Australian and Canadian data; the slightly different immigrant cohorts defined in the U.S. data are as follows: pre-1970, 1970-74, 1975-79, 1980-84, and 1985-90. The immigrant cohort coefficients reported in this table have been normalized to represent immigrant-native income differentials for men who are aged 25-29 (in both specifications) and who have 12 years of education (in specification (2)). Sampling weights were used in the U.S. calculations. 
Table 11

Income Regressions, Excluding Immigrants from Central/South America

Age, Education, and Fluency Coefficients

Destination Country

\begin{tabular}{|c|c|c|c|c|c|c|}
\hline \multirow[b]{2}{*}{ Regressor } & \multicolumn{2}{|c|}{ Australia } & \multicolumn{2}{|c|}{ Canada } & \multicolumn{2}{|c|}{ United States } \\
\hline & $(1)$ & $(2)$ & $(1)$ & (2) & $(1)$ & $(2)$ \\
\hline \multicolumn{7}{|l|}{ Age Group: } \\
\hline \multirow{2}{*}{$30-34$} & .112 & .095 & .252 & .236 & .235 & .222 \\
\hline & $(.012)$ & $(.012)$ & $(.007)$ & $(.007)$ & $(.013)$ & $(.013)$ \\
\hline \multirow[t]{2}{*}{$35-39$} & .137 & .120 & .370 & .350 & .374 & .334 \\
\hline & $(.013)$ & $(.013)$ & $(.007)$ & $(.007)$ & $(.013)$ & $(.013)$ \\
\hline \multirow[t]{2}{*}{$40-44$} & .173 & .169 & .445 & .434 & .496 & .441 \\
\hline & $(.014)$ & $(.014)$ & $(.007)$ & $(.007)$ & $(.014)$ & $(.013)$ \\
\hline \multirow[t]{2}{*}{$45-49$} & .168 & .194 & .466 & .488 & .555 & .524 \\
\hline & $(.015)$ & $(.016)$ & $(.008)$ & $(.008)$ & $(.015)$ & $(.015)$ \\
\hline \multirow[t]{2}{*}{$50-54$} & .121 & .153 & .449 & .518 & .580 & .585 \\
\hline & $(.017)$ & $(.017)$ & $(.009)$ & $(.009)$ & $(.017)$ & $(.016)$ \\
\hline \multirow[t]{2}{*}{$55-59$} & .013 & .050 & .421 & .525 & .580 & .601 \\
\hline & $(.020)$ & $(.022)$ & $(.010)$ & $(.010)$ & $(.018)$ & $(.017)$ \\
\hline \multicolumn{7}{|l|}{ Immigrant $\times$ Age Group: } \\
\hline \multirow[t]{2}{*}{$30-34$} & -.048 & -.035 & -.101 & .018 & -.022 & -.018 \\
\hline & $(.023)$ & $(.023)$ & $(.019)$ & $(.019)$ & $(.015)$ & $(.015)$ \\
\hline \multirow[t]{2}{*}{$35-39$} & -.008 & .011 & -.091 & .029 & -.010 & .026 \\
\hline & $(.025)$ & $(.025)$ & $(.018)$ & $(.019)$ & $(.016)$ & $(.015)$ \\
\hline \multirow[t]{2}{*}{$40-44$} & -.007 & .001 & -.075 & .025 & -.038 & .021 \\
\hline & $(.025)$ & $(.025)$ & $(.018)$ & $(.018)$ & $(.016)$ & $(.016)$ \\
\hline \multirow[t]{2}{*}{$45-49$} & -.068 & -.050 & -.072 & .006 & -.057 & .004 \\
\hline & $(.027)$ & $(.028)$ & $(.019)$ & $(.019)$ & $(.018)$ & $(.018)$ \\
\hline \multirow[t]{2}{*}{$50-54$} & -.104 & -.068 & -.119 & -.034 & -.104 & -.043 \\
\hline & $(.030)$ & $(.032)$ & $(.020)$ & $(.020)$ & $(.020)$ & $(.019)$ \\
\hline \multirow[t]{2}{*}{$55-59$} & .026 & .058 & -.153 & -.080 & -.137 & -.051 \\
\hline & $(.033)$ & $(.037)$ & $(.022)$ & $(.022)$ & $(.021)$ & $(.020)$ \\
\hline \multirow[t]{2}{*}{ Education } & & .057 & & .064 & & .090 \\
\hline & & $(.002)$ & & $(.001)$ & & $(.002)$ \\
\hline \multirow[t]{2}{*}{ Immigrant $\times$ Education } & & -.004 & & -.024 & & -.029 \\
\hline & & $(.003)$ & & $(.001)$ & & $(.002)$ \\
\hline \multicolumn{7}{|l|}{$\begin{array}{l}\text { Ability to Speak English } \\
\text { (or French in Canada): }\end{array}$} \\
\hline \multirow[t]{2}{*}{ Well or Very Well } & & -.164 & & -.171 & & -.089 \\
\hline & & $(.013)$ & & $(.010)$ & & $(.018)$ \\
\hline \multirow[t]{2}{*}{ Not at All or Not Well } & & -.425 & & -.222 & & -.236 \\
\hline & & $(.034)$ & & $(.032)$ & & $(.023)$ \\
\hline
\end{tabular}

Note: These coefficients are from the same income regressions reported in the Table 10; see the note to that table for more information. Standard errors are shown in parentheses. The reference group for the age dummies is 25-29 year-olds. The reference group for the fluency dummies is men who speak only English in the Australian and U.S. data, and men who speak only English and/or French in the Canadian data. 
Figure 1

Predicted Immigrant-Native Income Differentials

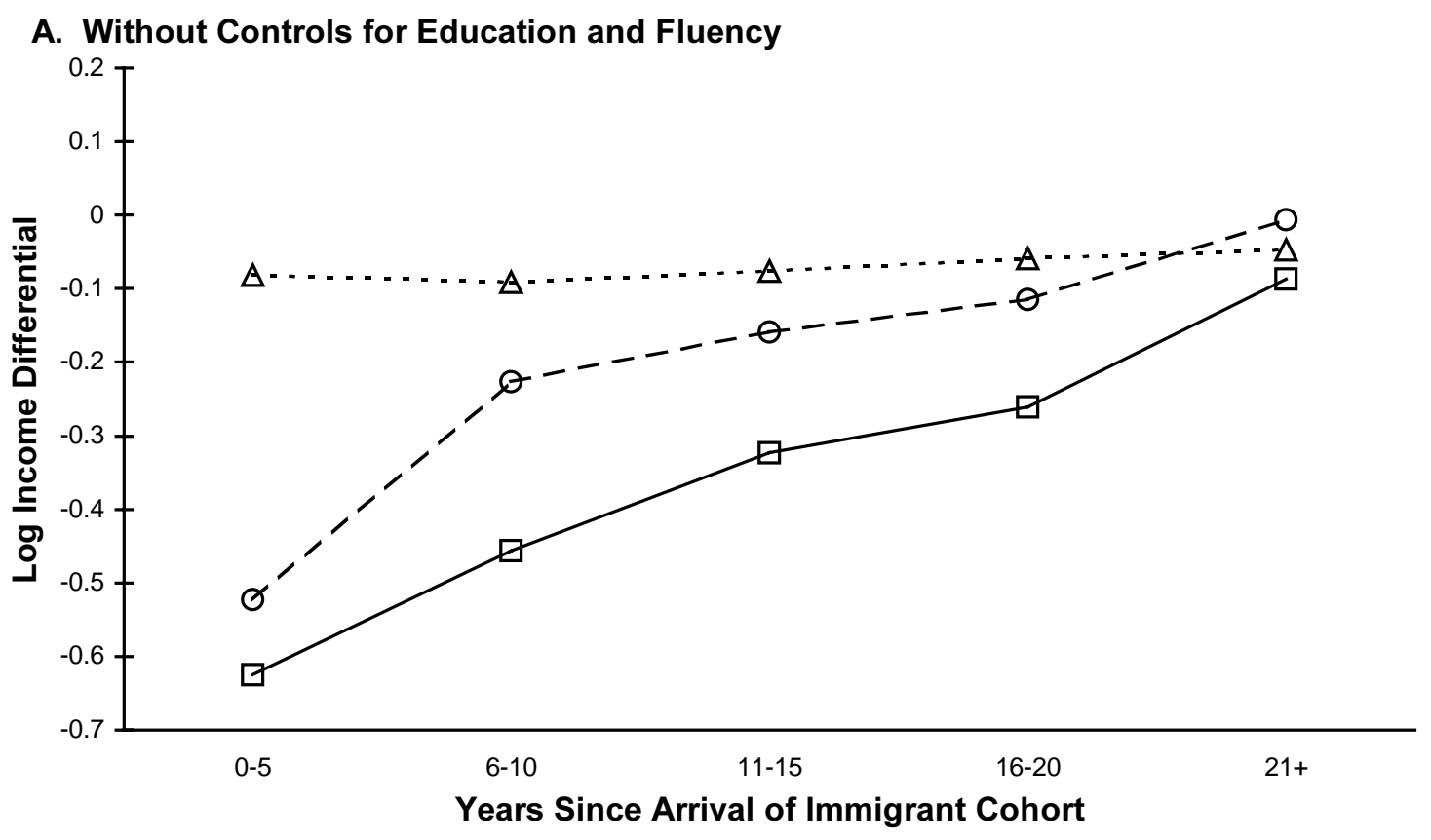

B. With Controls for Education and Fluency

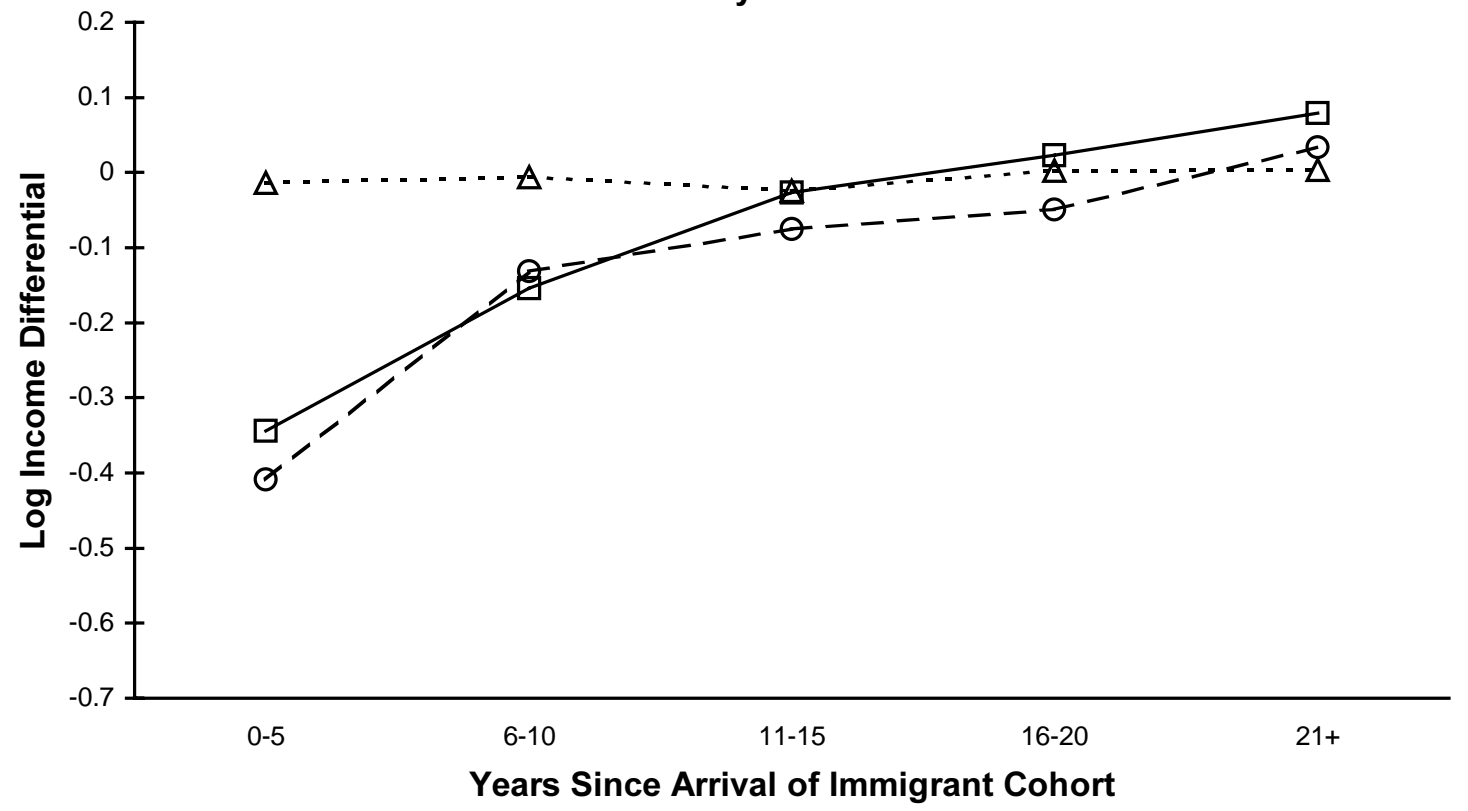

- $\Delta$ - Australia $\quad-\ominus-$ Canada $\quad \square-$ U.S. 
Figure 2

Predicted Immigrant-Native Income Differentials

Excluding Latin American Immigrants

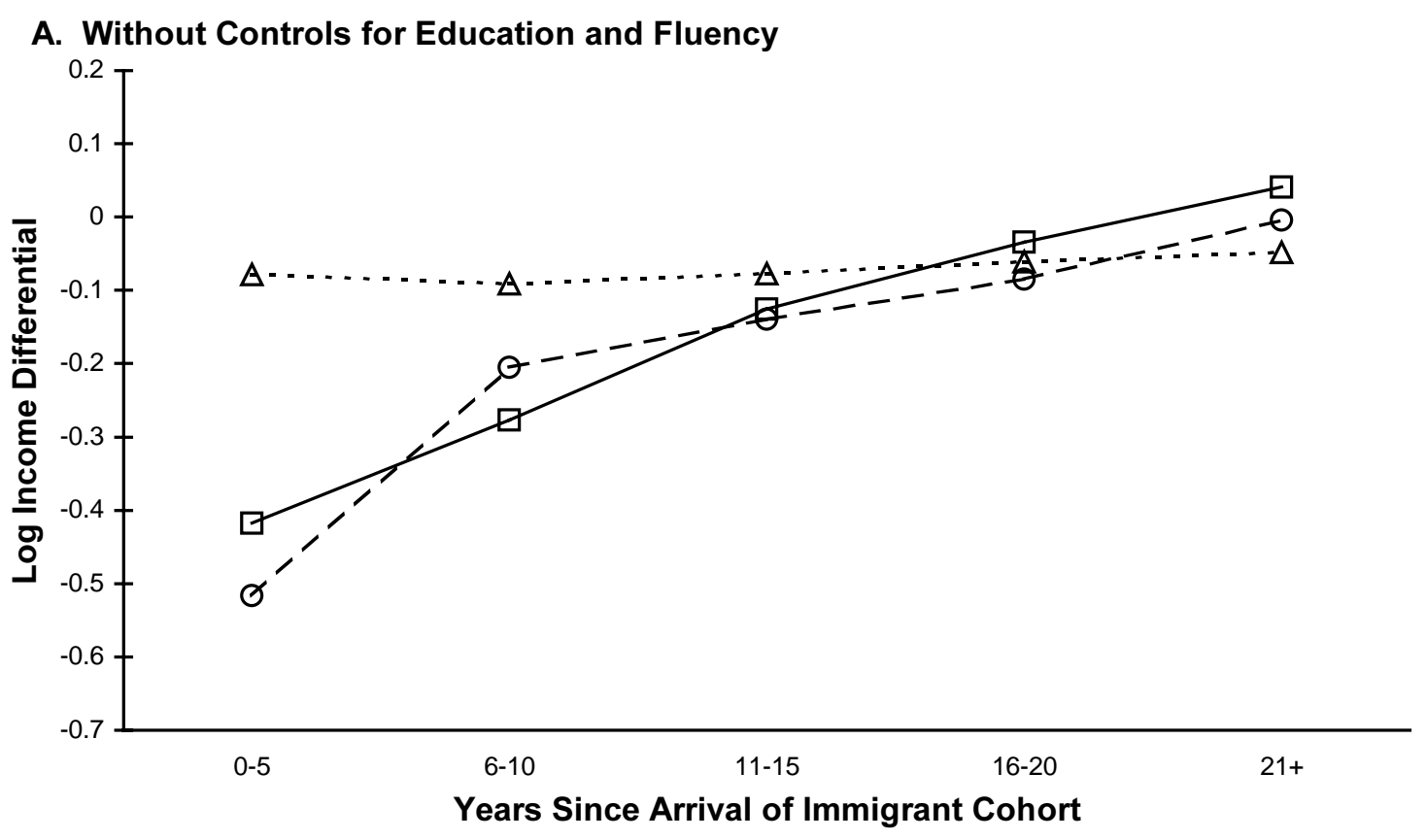

B. With Controls for Education and Fluency

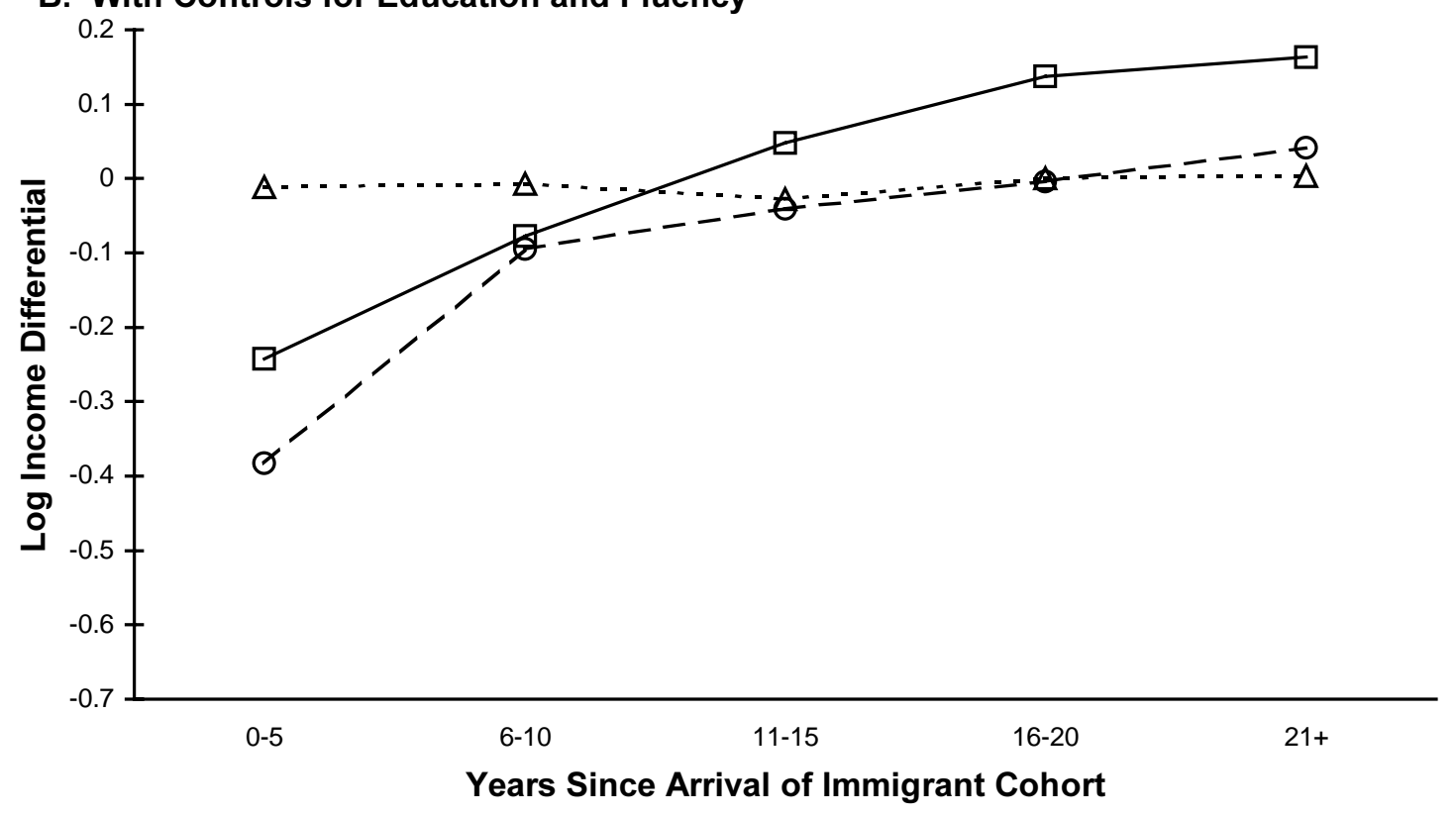

$\cdots \Delta \cdots$ Australia $\quad-\ominus-$ Canada $\square-$ U.S. 


\section{IZA Discussion Papers}

\author{
No. Author(s) \\ 290 \\ D. A. Cobb-Clark \\ M. D. Connolly \\ C. Worswick
}

291

R. T. Riphahn

292

E. Wasmer

293

294

D. Cobb-Clark

T. F. Crossley

295

F. Duffy

P. P. Walsh

296

H. S. Nielsen

M. Rosholm

N. Smith

L. Husted

297

J. C. van Ours

J. Veenman

298

P. Telhado Pereira

P. Silva Martins

299
G. Brunello
C. Lucifora
R. Winter-Ebmer

300
A. Stutzer
R. Lalive

301

J. R. Frick

G. G. Wagner

Title

Area

Date

The Job Search and Education Investments of

1

04/01 Immigrant Families

Cohort Effects in the Educational Attainment of Second Generation Immigrants in Germany: An Analysis of Census Data

Between-group Competition in the Labor Market and the Rising Returns to Skill: US and France 1964-2000

Gender, Comparative Advantage and Labor

Market Activity in Immigrant Families

Estimating the Effect of Unemployment Insurance Compensation on the Labor Market Histories of Displaced Workers

Individual Pay and Outside Options:

Intergenerational Transmissions and the Schoolto-Work Transition of $2^{\text {nd }}$ Generation Immigrants

$05 / 01$

The Educational Attainment of Second

05/01

Generation Immigrants in The Netherlands

1

5

06/01

Returns to Education and Wage Equations

5

06/01

Students

5

06/01

Searching and Subjective Well-Being

Economic and Social Perspectives of Immigrant

1

06/01 

H. Bonin
G. Abío
E. Berenguer
J. Gil
C. Patxot

307

G. A. Pfann 

A. Frederiksen
E. K. Graversen
N. Smith

Germany: The Impact on Productivity and Wages 

Quality
A. Ibourk
B. Maillard
S. Perelman
H. R. Sneessens

The Matching Efficiency of Regional Labour

Markets: A Stochastic Production Frontier

Estimation, France 1990-1995 

ment Compensation System is More Prone to Labor Market Shocks? 
$360 \quad J$. Hansen M. Lofstrom

$361 \quad$ M. C. Berger J. S. Earle

K. Z. Sabirianova

362

$$
\text { J. Angrist }
$$

V. Lavy

363

H. Antecol

D. A. Cobb-Clark

S. J. Trejo
The Dynamics of Immigrant Welfare and Labor Market Behavior

Worker Training in a Restructuring Economy:

4 Evidence from the Russian Transition

New Evidence on Classroom Computers and Pupil Learning

6

Immigration Policy and the Skills of Immigrants

2

to Australia, Canada, and the United States 